\title{
Effect of Electroporation Conditions on Loach Sperm for Successful Gene Transfer and Early Development
}

\author{
Yee-Liang Chen and Huai-Jen Tsai ${ }^{\dagger}$ \\ Institute of Fisheries Science, National Taiwan University, Taipei 106, Taiwan
}

(Received August 7, 1996)

\begin{abstract}
We used loach Misgurnus anguillicaudatus sperm to study the effect of the electroporation conditions for fish sperm on the capacity of transferring a foreign gene into the eggs and the development of their derivative embryos. Results showed that sperm electroporated at low field strengths resulted in a higher hatching rate and a lower abnormality rate, compared to the high field strength group. However, the success rate of gene transfer of the low field strength group was lower than that of the high field strength group. Sperm electroporated at a concentration of $175 \mu \mathrm{g} / \mathrm{m} l$ plasmid DNA had a higher gene transfer rate than did those at $100 \mu \mathrm{g} / \mathrm{m} l$ or lower. The hatching rate of embryos derived from ova fertilized with sperm treated at $250 \mu \mathrm{g} / \mathrm{m} /$ DNA decreased abruptly, even at a low field strength $(3.5 \mathrm{kV})$. Increasing the number of pulses per cycle (up to $2^{11}$ ) and the number of cycles (up to 12) enhanced the success rate of gene transfer. Dot and Southern blot analyses and PCR detection proved the existence of transferred DNA in embryos following sperm-electroporation. An optimal condition of electroporation for loach sperm to obtain normal development in transgenic loach is suggested.
\end{abstract}

Key words: electroporation, fish, gene transfer, sperm

Many approaches have been developed to introduce foreign DNA molecules into zygotes with varying degrees of success. In fish, the traditional method is microinjection of DNA into the nucleus of oocyte ${ }^{1,2)}$ and into the cytoplasm of fertilized eggs. ${ }^{3-5)}$ Another method is electroporation of DNA into fertilized eggs. ${ }^{6-8)}$

There could be some advantages in applying the spermmediated gene transfer technique to fish. Firstly, this technique is considered a "mass" gene transfer. Powers et al." reported that the efficiency of gene transfer by electroporation for fertilized eggs is ten to one hundred times greater than that of microinjection, although this is contrary to the conclusion of other laboratories. However, the transfer efficiency is still not high enough to treat the tremendous number of eggs which are spawned within a very short time by some fish. Secondly, this technique overcomes some disadvantages of conventional gene transfer systems due to the characteristics of fish embryos, i.e., opaqueness, stickiness or buoyancy of the embryos, the invisibility of the pronuclei and the toughness of the chorion. Thirdly, foreign DNA should be transferred into the nucleus of oocyte by sperm. If fertilized eggs were electroporated with foreign DNA, the DNA fragments would have greater chances to be transferred into a place other than the blastodisc because the volume of the blastodisc is extremely small in the fertilized egg. Fourth, fish sperm are relatively easier to handle than mammal sperm since simply adding water is enough to activate fish sperm. Therefore, recently fish sperm have been reported as a vector for introducing foreign DNA to produce transgenic fish. Although Chourrout and Perrot ${ }^{9 y}$ reported failure by using sperm-incubation for rainbow trout, some successful attempts have been reported: sperm-incubation for zebrafish; ${ }^{10)}$ sperm-electroporation for common carp, catfish, tilapia;11) salmon; ${ }^{12,13)} \operatorname{loach}^{147}$; and zebrafish. ${ }^{15)}$ Sperm-electroporation seems to be a more promising approach. However, Tsai et $a .^{(4)}$ reported that the fertilization rate of eggs derived from electroporated sperm was lower than that of eggs derived from untreated sperm. In addition, a high percentage of morphological abnormality was found in the transgenic loach. These observations suggest that loach sperm were treated under non-optimal conditions.

In this report; we study the relationships of the electroporation (Baekonization) conditions used for fish sperm, the capacity of gene transfer mediated by sperm and the development of embryos derived from the treated sperm.

\section{Materials and Methods}

\section{Experimental Animals}

Mature loach, Misgurnus anguillicaudatus, weighing 44-78 g, were purchased locally. Procedures used for ovulation induction, gamete collection, preparation, and in vitro fertilization were as previously described. ${ }^{14}$

\section{Fertilization Rate, Hatching Rate and Abnormality Rate}

Fertilization rate of eggs was calculated by comparing the number of 2-cell stage (two to three hours after fertilization) embryos to the total of 250 eggs scored. Hatching rate of embryos was calculated by comparing the number of fry which hatched from a fixed area of the plastic container at eighteen hours post-fertilization to the total of 250 eggs scored. Abnormality rate of fry was calculated by comparing the number of 2-day fry having abnormal ap-

\footnotetext{
${ }^{t}$ To whom correspondence should be addressed.
} 
pearance to the total of 1002-day control fry. Morphological abnormalities included two heads, duplicity, curled body, floating and strange abdominal shape.

\section{Transferred DNA}

Plasmids of pUC19 $(2.7 \mathrm{~kb})^{16)}$ and pOP5MGH2 $(7.6 \mathrm{~kb}),{ }^{17)}$ donated by Choy Hew, University of Toronto, were prepared by cesium chloride-ethidium bromide ultracentrifugation ${ }^{18)}$ and linearized by digestion with EcoRI. Plasmid pOP5MGH2 consists of a segment encoding chinook salmon growth hormone cDNA driven by an antifreeze protein promoter of ocean pout.

\section{Electroporation Conditions}

A noncontact mode instrument (Baekon 2000, Baekon Inc., CA) was used to carry out electroporation. The electric field strength was varied from $0,2,2.5,3,3.5,4,6$ to $8 \mathrm{kV}$; the number of pulses per cycle was varied from $2^{0}, 2^{6}$ to $2^{11}$; the number of cycles was varied from $0,6,8$ to 12 . Other parameters remained constant: the pulse time was $120 \mu \mathrm{s}$; the burst time was $1.6 \mathrm{~s}$; the distance between the electrode and the surface of DNA solution was $1 \mathrm{~mm}$; and the solution volume was $100 \mu \mathrm{l}$ in a $1-\mathrm{m} /$ cuvette. For electroporation, $100 \mu \mathrm{l}$ buffered saline solution $(0.7 \% \mathrm{NaCl}$, $0.1 \%$ disodium edetate and $0.1 \%$ sorbic acid) contained $10^{7}$ sperm cells with $10,17,5$ and $25 \mu \mathrm{g}$ foreign DNA, respectively, for the experimental group. Buffered saline solution alone was used for the mock-treated group, and untreated sperm were used for the control group.

\section{Genomic DNA Extraction, Dot and Southern Blot Ana- lyses}

The genomic DNA was extracted from 2-day fry and 2week fry by the SDS-phenol method. ${ }^{6}$ After extraction, genomic DNA was quantified by GeneQuant (Pharmacia, USA). Next, $1.2 \mu \mathrm{g}$ of DNA was spotted onto a nylon membrane (Schleicher \& Schuell Inc., USA). After the DNA was cross-linked to the membrane by UV irradiation and then hybridized to a ${ }^{32} \mathrm{P}$-labeled probe, a $2.7 \mathrm{~kb}$ EcoRI-digested pUC19 that was prepared by the random priming method. ${ }^{19)}$

The genomic DNA extracted from 15 pooled embryos of 64-cell stage was subjected to Southern blot analysis. The total extracted DNA (approximately $0.025 \mu \mathrm{g}$ ) was digested with EcoRI, electrophoresed on an agarose gel, transferred to a nylon membrane, and then hybridized to a probe. Hybridization was carried out at $42^{\circ} \mathrm{C}$ overnight in a solution of $50 \%$ formamide, $5 \times$ Denhart's solution, $0.1 \%$ SDS, $5 \times$ SSPE ( $1 \times$ SSPE: $0.15 \mathrm{M} \mathrm{NaCl}, 11 \mathrm{mM}$ $\mathrm{NaH}_{2} \mathrm{PO}_{4}$ and $1 \mathrm{mM}$ EDTA) and a denatured probe. The washing conditions ( $20 \mathrm{~min}$ each) were: $4 \times \mathrm{SSC}$ and $0.1 \%$ SDS at room temperature; $2 \times \mathrm{SSC}$ and $0.1 \%$ SDS at $37^{\circ}$ $\mathrm{C} ; 1 \times \mathrm{SSC}$ and $0.5 \%$ SDS at $42^{\circ} \mathrm{C} ; 0.5 \times \mathrm{SSC}$ and $0.5 \%$ $\mathrm{SDS}$ at $55^{\circ} \mathrm{C}$; and $0.1 \times \mathrm{SSC}$ and $0.5 \% \mathrm{SDS}$ at $68^{\circ} \mathrm{C}$.

\section{PCR Analyses}

Forward ( $5^{\prime}$-TCTGCTGATGCCAGTCTTACT-3') and reverse primers $\left(5^{\prime}\right.$-ACAGAAGTCCAGCAGGAATAT $\left.3^{\prime}\right)$ were used for PCR analysis. ${ }^{20)}$ These primers were reported to be a reliable set for detecting the plasmid pOP5MGH2, which encodes the exogenous chinook salmon GH cDNA in the transgenic loach, because it gener- ated an unique 199 bp PCR-product. ${ }^{14)}$

The genomic DNA samples were extracted from 2-week fry which were derived from sperm electroporated at 3.5 $\mathrm{kV}, 2^{11}$ pulses for 12 cycles in the presence of $175 \mu \mathrm{g} / \mathrm{m} l$ pOP5MGH2. PCR was carried out in $100 \mu$ lof a solution consisting of 20-30 ng templates, $10 \mathrm{pmol}$ of each primer, $200 \mu \mathrm{M}$ of each dNTP, $10 \mu \mathrm{g}$ of bovine serum albumin, $1.75 \mathrm{mM} \mathrm{MgCl}_{2}$ and $1 \mathrm{U}$ Taq DNA polymerase in a $1 \times$ PCR buffer (Promega). Amplification was performed using a DNA Thermal Cycler (Perkin-Elmer Cetus, Norwalk, CT). PCR consisted of twenty-five cycles denaturing at $92^{\circ} \mathrm{C}$ for $1 \mathrm{~min}$, annealing at $50^{\circ} \mathrm{C}$ for $2 \mathrm{~min}$ (the first 5 cycles at $60^{\circ} \mathrm{C}$ ) and extension at $72^{\circ} \mathrm{C}$ for $3 \mathrm{~min}$. After the last cycle, an extension of $10 \mathrm{~min}$ at $72^{\circ} \mathrm{C}$ was used to complete the reaction. Each PCR sample was subjected to electrophoresis on a 3\% NuSieve GTG agarose gel (FMC BioProducts, USA).

\section{Results}

\section{Effect of Field Strength on Rates of Hatching and Gene Transfer}

An aliquot of $100 \mu l$ buffered saline solution containing $10^{7}$ sperm was electroporated in the absence of DNA fragments at field strength ranging from $2,2.5,3,3.5,4,6$ to 8 $\mathrm{kV}$, at $2^{6}$ pulses for 6 cycles with a pulse time of $120 \mu \mathrm{s}$ and a burst time of $1.6 \mathrm{~s}$. The results showed that the hatching rate of loach embryos derived from ova fertilized with electroporated sperm showed a stepwise decline as field strength increased, with a rapid change from 3 to $4 \mathrm{kV}$ and relatively little change otherwise, compared to the $31 \%$ hatching rate of the untreated control group (Fig. 1).

For estimating the gene transfer rate, sperm were electroporated in the presence of $100 \mu \mathrm{g} / \mathrm{m} l$ linear pUC19 at 4,6 or $8 \mathrm{kV}$, but other variables were kept constant $\left(2^{6}\right.$ pulses for 6 cycles, $1.6 \mathrm{~s}$ burst time and $120 \mu \mathrm{s}$ pulse time). Total DNA was extracted from 2-week fry and analyzed by dot blotting. The results showed that the success rate of gene transfer increased as field strength increased: $35 \%$ of positive embryos at $4 \mathrm{kV}$ ( 7 out of 20 ); $45 \%$ at $6 \mathrm{kV}$ ( 9 out of 20 ); and $55 \%$, at $8 \mathrm{kV}$ (11 out of 20 ) (Fig. 1).

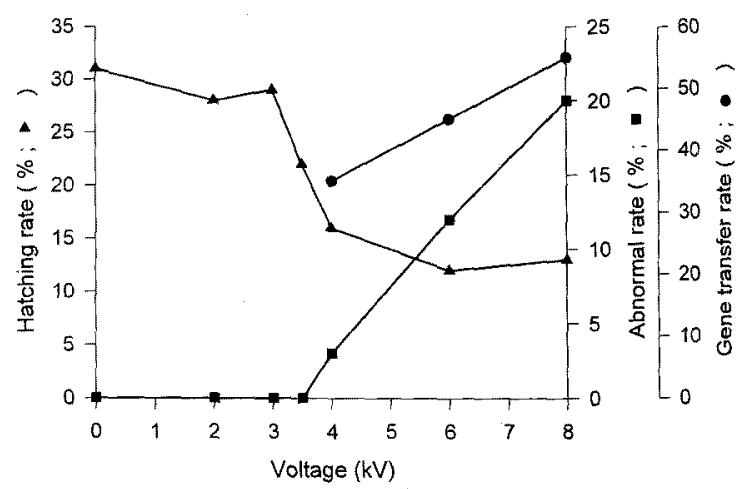

Fig. 1. Effect of voltage for sperm on hatching rate (triangles), abnormality rate (squares) and gene transfer rate (circles) of loach embryos.

These embryos were derived from ova fertilized with sperm electroporated at various field strengths in the absence of DNA while other electroporation parameters remained constant at $2^{6}$ pulses for $6 \mathrm{cycles}$, with a pulse time of $120 \mu \mathrm{s}$, and a burst time of $1.6 \mathrm{~s}$. 
Effect of Field Strength on Abnormality Rate of Embryos

The abnormality rate of fry derived from ova fertilized with sperm electroporated at $2^{6}$ pulses for 6 cycles without DNA molecules increased as field strength increased from 3.5 to $8 \mathrm{kV}$ (Fig. 1).

\section{Effect of DNA Concentration on Hatching Rate and Gene Transfer Rate}

The hatching rate in the presence of 100,175 , and 250 $\mu \mathrm{g} / \mathrm{ml}$ of linear pUC19 was studied in embryos derived from ova fertilized with sperm treated at $3.5 \mathrm{kV}, 2^{6}$ pulses for 6 cycles, with a pulse time of $120 \mu \mathrm{s}$, and a burst time of $1.6 \mathrm{~s}$. Figure 2 shows that the hatching rate was not different among the $100,175 \mu \mathrm{g} / \mathrm{m} l$ and control (ova fertilized with untreated sperm) groups; whereas the hatching rate declined abruptly for the $250 \mu \mathrm{g} / \mathrm{ml}$ group (Fig. 2). However, based on dot blot analysis, the success rates of gene transfer for the 100,175 and $250 \mu \mathrm{g} / \mathrm{ml}$ groups were $28.5 \%$ (10 out of 35 ), $43.3 \%$ (13 out of 30 ) and $60 \%$ (19 out of 32), respectively (Fig. 2).

Effect of Increasing Number of Pulses and Number of Cycles on Fertilization Rate and Gene Transfer Rate

The rate of eggs developing to the 2-cell stage embryos derived from ova fertilized with sperm electroporated at a pulse time of $120 \mu \mathrm{s}$, a burst time of $1.6 \mathrm{~s}$, and at field strengths of $2,2.5,3.5,4$, and $6 \mathrm{kV}$, respectively, was not affected by increasing numbers of pulses and cycles from $2^{6}$ and 6 to $2^{11}$ and 8, respectively (Fig. 3).

Sperm were electroporated at $3.5 \mathrm{kV}, 2^{11}$ pulses for 8 and 12 cycles, respectively, in the presence of $175 \mu \mathrm{g} / \mathrm{m} l$ linear pUC19. The existence of transferred plasmid in the total DNA of 2-day fry was detected by dot blot analysis (Fig. 4). The results showed that transfer rates were $45 \%$ ( 9 out of 20) and $70 \%$ (14 out of 20) for 8 and 12 cycles, respectively (Fig. 5).

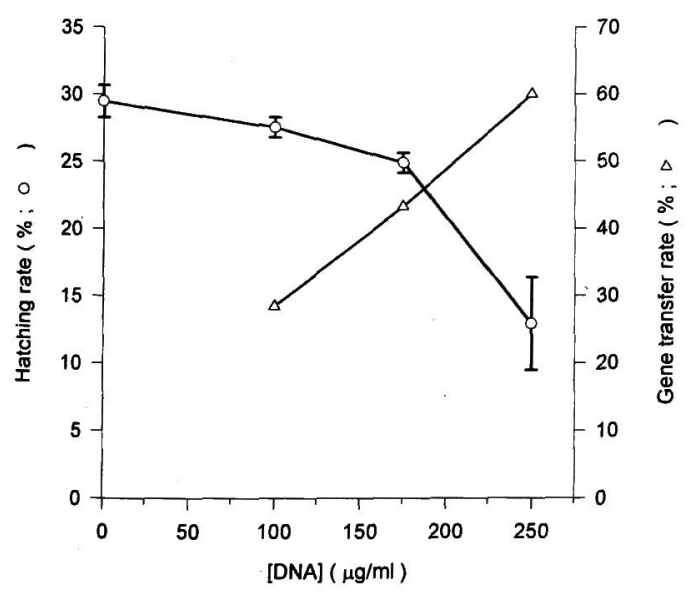

Fig. 2. Effect of concentration of DNA on hatching rate (circles) and gene transfer rate (triangles) of embryos.

Embryos were derived from ova fertilized with sperm electroporated at $3.5 \mathrm{kV}, 2^{6}$ pulses for 6 cycles, with a pulse time of $120 \mu \mathrm{s}$, and a burst time of $1.6 \mathrm{~s}$ in the presence of various concentrations $(0,100$, 175 and $250 \mu \mathrm{g} / \mathrm{m} l)$ of pUC19. Data is presented as mean \pm SD $(n=3)$.

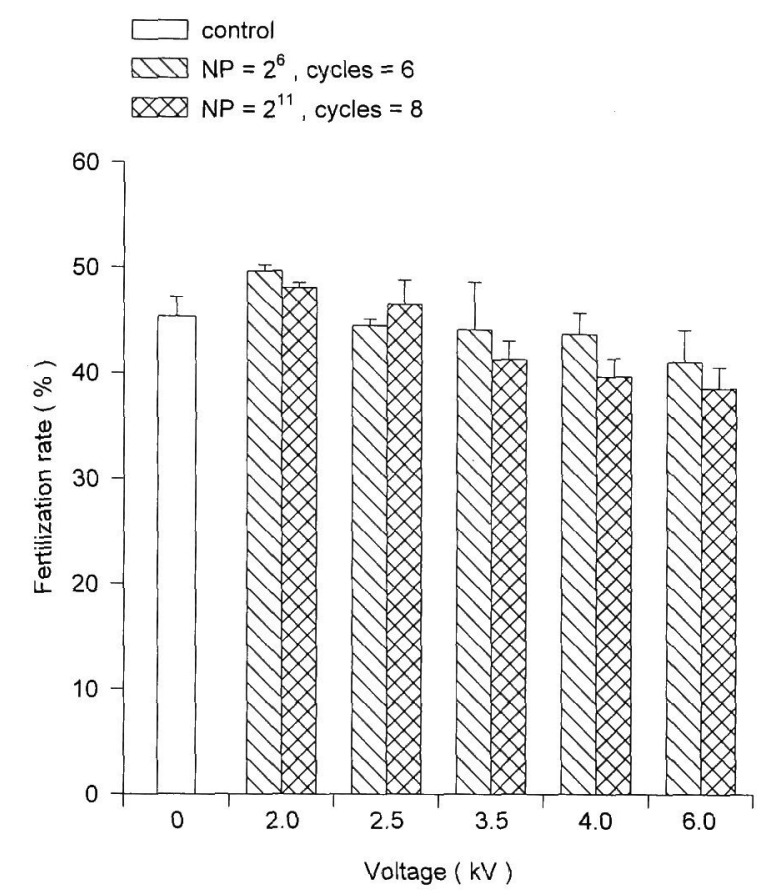

Fig. 3. Comparison of fertilization rate of loach embryos derived from electroporated sperm.

Embryos developing to 2-cell stage were calculated among 250 eggs. Sperm were from the untreated group $(0 \mathrm{kV}$, as a control, open bar) and from electroporated groups. Sperm from the latter groups were electroporated at various field strengths and at $2^{6}$ pulses (NP) for 6 cycles (diagonally hatched bar) or $2^{11}$ pulses for 8 cycles (crosshatched bar). Data is presented as mean $\pm \operatorname{SD}(n=3)$.

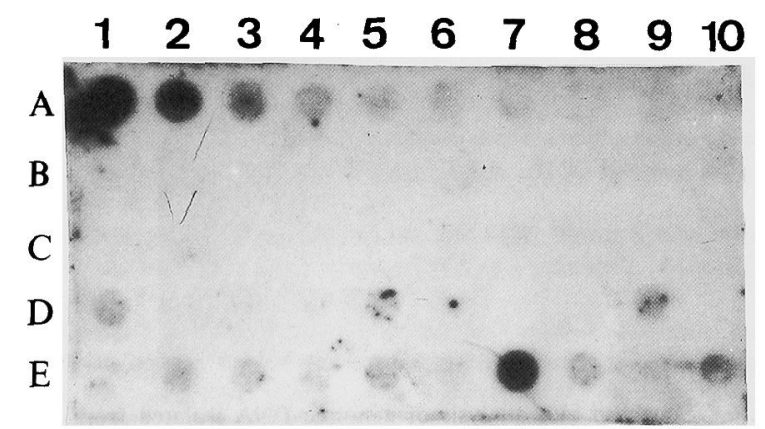

Fig. 4. Dot blot analysis of genomic DNA of loach fry.

Two-day fry derived from ova fertilized with sperm electroporated at 8 cycles (row D) and 12 cycles (row E) in the presence of 175 $\mu \mathrm{g} / \mathrm{ml}$ pUC19 while other parameters remained constant at $3.5 \mathrm{kV}$, $2^{11}$ pulses, with a pulse time of $120 \mu \mathrm{s}$, and a burst time of $1.6 \mathrm{~s}$. Row A 1-7 represents pUC19 (positive control) at concentrations of 100 , $40,20,10,5,1$ and $0.5 p g$, respectively. Rows $B$ and $C$ represent the untreated control and mock-treated control, respectively.

\section{Fate of the Transferred DNA}

Genomic DNA was extracted from 15 embryos at the 64-cell stage and was analyzed by Southern blotting. These embryos were derived from ova fertilized with sperm electroporated at $3.5 \mathrm{kV}, 2^{11}$ pulses for 12 cycles, with a pulse time of $120 \mu \mathrm{s}$, and a burst time of $1.6 \mathrm{~s}$ in the presence of linearized pUC19 at a concentration of $175 \mu \mathrm{g} / \mathrm{ml}$. The 


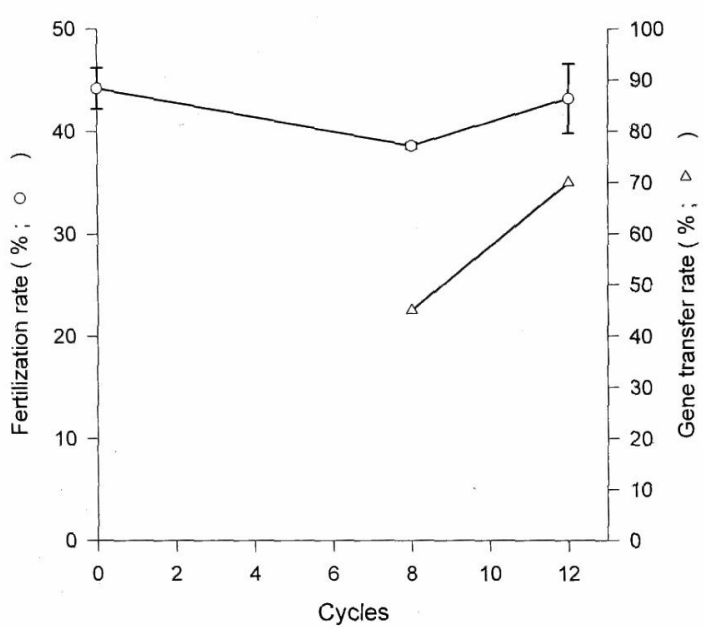

Fig. 5. Effect of electroporation cycles on fertilization rate (circles) and gene transfer rate (triangles) of loach embryos.

Sperm were from the untreated group $(0 \mathrm{kV}$, as a control) and from the electroporated groups, which were treated at $3.5 \mathrm{kV}, 2^{11}$ pulses for 8 or 12 cycles in the presence of $175 \mu \mathrm{g} / \mathrm{m} /$ DNA. Fertilization rate is presented as mean $\pm \operatorname{SD}(n=3)$.

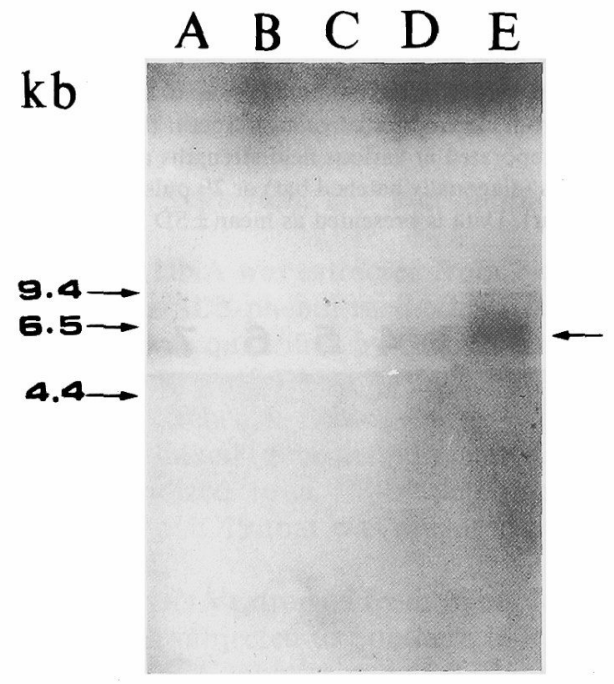

Fig. 6. Southern blot analysis of genomic DNA isolated from 15 64cell-stage embryos derived from ova fertilized with electroporated sperm.

Genomic DNA was digested with EcoRI, electrophoresed on an agarose gel and hybridized with ${ }^{32} \mathrm{p}$-labelled probe, pUC19. Lane A, molecular marker in kilobase pairs $(\mathrm{kb})$; lane B, embryos derived from ova fertilized with untreated sperm; lane $C$, embryos derived from ova fertilized with sperm electroporated in the absence of DNA; lanes D and E, embryos derived from ova fertilized with sperm electroporated with pUC19. Arrow indicates the transgene.

results showed that a positive band was located at a position with a molecular size of 6 and $6.4 \mathrm{~kb}$, respectively, which was higher than that of the transgene pUC19 (2.7 kb) (lanes D and E, Fig. 6). As expected, embryos derived from ova fertilized with untreated sperm and the electroporated sperm in the absence of pUC19 (mock-treated group) were negative (lanes B and C, Fig. 6).

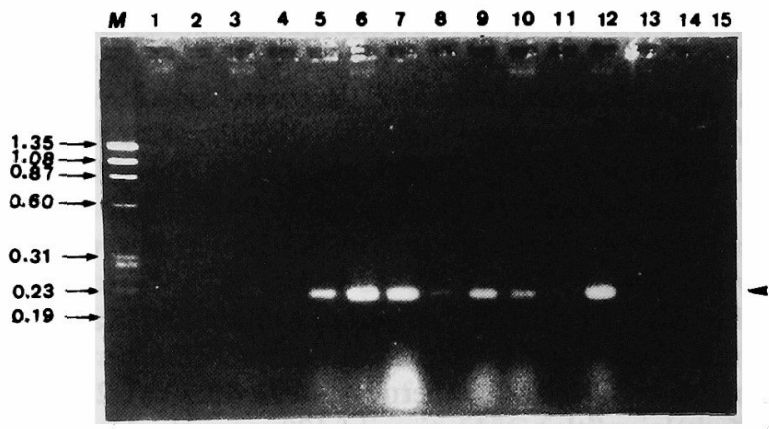

Fig. 7. PCR analyses of genomic DNA isolated from 2-week-old loach. Primers are described in the text. Lane M, molecular markers, HaeIII-digested $\phi \mathrm{X}$-174-RF DNA; lanes I-3, from untreated control; lanes 4-15, from the experimental group. Arrow indicates the PCR product (199 bp).

In case that $\mathrm{pOP} 5 \mathrm{MGH} 2$ fragment was employed, we detected the existence of the transgene in the genome of 2week loach fry by PCR. A 199 bp product was generated in transgenic loach (lanes 5-10 and 12, Fig. 7). On the other hand, when primers were used for PCR of total DNA isolated either from the non-transgenic loach in the experimental group (lanes 4, 11 and 13-15, Fig. 7) or from the control loach (lanes 1-3, Fig. 7), no PCR product was produced. The success rate of gene transfer was 54\% (13 positives out of 24 examined samples).

\section{Discussion}

Figure 1 shows that the higher the field strength used for treating the sperm, the lower the resulting hatchability of embryos. This supports the result reported by Tsai et al ${ }^{14)}$ that the most influential variable for sperm mobility among electroporation parameters was amplitude. They found that sperm mobility was gradually lost when the amplitude increased above $8 \mathrm{kV}$ while other variables were constant. This result is also consistent with the results of electric field-induced DNA transfection of cell culture, which was reported by Xie and Tsong. ${ }^{21)}$ They found that the survival rate of cells decreased if voltage increased.

Nevertheless, a higher field strength for treating sperm, on the other hand, resulted in a higher success rate of gene transfer; i.e., 35,45 and $55 \%$ at 4,6 and $8 \mathrm{kV}$, respectively. We suggest that more foreign DNA molecules might be introduced into sperm electroporated at higher field strength rather than at lower field strength. As a result, the transfer efficiency increased at high field strength. However, a field strength which is too high might physically destroy the integrity of genome, cell membrane, organella and so on, which could lead to a lower hatchability rate, lower survival rate and higher abnormality rate of embryos.

Increasing the DNA concentration alone at a relatively low field strength resulted in reduced hatching rate of loach embryos. The hatching rate was dramatically decreased when $250 \mu \mathrm{g} / \mathrm{ml}$ was used to electroporate sperm, compared to those of $100 \mu \mathrm{g} / \mathrm{ml}$ and $175 \mu \mathrm{g} / \mathrm{ml}$ treatments. This result agreed with the report of Winterbourne et al. ${ }^{22)}$ They demonstrated that when over $200 \mu \mathrm{g} /$ $\mathrm{m} l$ DNA was used to electroporate cells, most cells died. 
There is also evidence in the toxicity of microinjected DNA at high concentrations. ${ }^{1,2)}$ Thus, we suggest that too high a concentration of DNA may cause too many DNA molecules to be introduced into cells, which would be toxic to embryos. However, the transfer efficiency is dependent on the concentration of plasmid DNA introduced. The hatching rate of embryos derived from sperm electroporated at either 100 or $175 \mu \mathrm{g} / \mathrm{m} /$ did not differ significantly from that of the control group. The success rate of gene transfer for sperm electroporated at $175 \mu \mathrm{g} / \mathrm{ml}$ was superior to that of sperm electroporated at $100 \mu \mathrm{g} / \mathrm{m} l: 43.3 \%$ vs $28.5 \%$, respectively, and the gene transfer rate of the $250 \mu \mathrm{g} / \mathrm{m} /$ group reached as high as $60 \%$.

The transfer efficiency of electroporated sperm is also related to the numbers of cycles and pulses during electroporation. The fertilization rate of eggs did not differ between the group of 6 cycles and $2^{6}$ pulses and the group of 12 cycles and $2^{11}$ pulses. However, the gene transfer rate was substantially increased if the numbers of cycles and pulses were raised, i.e., up to $70 \%$ in the presence of 175 $\mu \mathrm{g} / \mathrm{m} l \mathrm{pUC1}$ DNA. Therefore, gene transfer efficiency is enhanced simply by increasing the numbers of pulses and cycles. This result supports those of Wolf et al. ${ }^{23)}$ who conducted experiments on the electroporation of mammalian cells and concluded that increasing the number of pulses helped gene transfer.

It is interesting to note that the success rate of transgenesis might also be dependent on the species of transgene even if sperm are treated under the above electroporation conditions, for example, in case pOP5MGH2 DNA fragments were used to transfer instead of pUC19 DNA. When 2-week loach fry were examined by PCR, we found that the success rate of gene transfer was $54 \%$, which was lower than that of the pUC19 transgene, $70 \%$. In addition, the survival rate of fry derived from ova fertilized with pUC19-treated sperm was higher than that of fry derived from pOP5MGH2-treated sperm. Genes encoded in pUC19 are of prokaryotic origin. They are hardly expressed in fish. No resultant product is produced that influences fish development. On the contrary, the pOP5MGH2 fragment encodes an exogenous growth hormone gene. Overexpression or improper expression of the pOP5MGH2 transgene during embryogenesis might have a negative effect. Thus, it is reasonable that the success rate of pOP5MGH2 gene transfer was lower than that of pUC19 gene transfer if we examined the 2 -week survival fry.

Southern blot analysis of total DNA extracted from 64cell-stage embryos showed positive bands with molecular size of 6 and $6.4 \mathrm{~kb}$, which were higher than that of the transgene pUC19 $(2.7 \mathrm{~kb})$. We propose that two digested linear plasmids might form dimer and link to genomic DNA. The integrated DNA fragments might be rearranged. Consequently, an unpredictable size of fragment was observed.

Tsai et al. ${ }^{14)}$ reported that the fertilization rate of ova fertilized with electroporated sperm was lower than that of ova fertilized with untreated sperm. Furthermore, a relatively high percentage of morphological abnormality was found in the gene transfer group. One reason for these consequences might be because loach sperm was improperly treated. In this study, we optimized the conditions for loach sperm which resulted in normally developed transgenic individuals. That is, we electroporated sperm at 3.5 $\mathrm{kV}, 2^{11}$ pulses for 12 cycles, with a burst time of $1.6 \mathrm{~s}$, and a pulse time of $120 \mu \mathrm{s}$ in the DNA concentration of 17.5 $\mu \mathrm{g}$.

Acknowledgments This work was supported by grants from the National Science Council, Republic of China, NSC83-0409-B002-027.

\section{References}

1) K. Ozato, H. Kondoh, H. Inohara, T. Iwamatsu, Y. Wakamatsu, and T. S. Okada: Production of transgenic fish: introduction and expression of chicken $\delta$-crystallin gene in medaka embryos. Cell Differ., 19, 234-237 (1986)

2) H. J. Tsai, S. H. Wang, K. Inoue, M. Kimura, Y. Wakamatsu, and K. Ozato: Initiation of the transgenic lac $Z$ gene expressed in medaka (Oryzias latipes) embryos. Mol. Marine Biol. Biotechnol., 4, 1-9 (1995).

3) D. Chourrout, R. Guyomard, and L. M. Houdebine: High efficiency gene transfer in rainbow trout (Salmo gairdneri) by microinjection into egg cytoplasm. Aquaculture, 51, 143-150 (1986).

4) G. L. Fletcher, M. A. Shears, M. J. King, P. L. Davies, and C. L. Hew: Evidence for antifreeze protein gene transfer in Atlantic salmon (Salmo salar). Can. J. Fish. Aquat. Sci. 45, 352-357 (1988).

5) J. K. Lu, T. T. Chen, C. L. Chrisman, O. M. Andrisani, and J. E. Dixon: Integration, expression, and germ-line transmission of foreign growth hormone genes in medaka (Oryzias latipes). Mol. Marine Biol. Biotechnol., 1, 366-375 (1992).

6) K. Inoue, S. Yamashita, J. Hata, S. Kabeno, S. Asada, E. Nagahi$\mathrm{sa}$, and T. Fujita: Electroporation as a new technique for producing transgenic fish. Cell Differ. Dev., 29, 123-128 (1990).

7) D. A. Powers, L. Herford, T. Cole, T. T. Chen, C. M. Lin, K. Knight, K. Creech, and R. Dunham: Electroporation: a method for transferring genes into the gametes of zebrafish (Brachydanio rerio), channel catfish (Ictalurus punctatus), and common carp (Cyprinus carpio). Mol. Marine Biol. Biotechnol., 1, 301-308 (1992).

8) H. J. Tsai and F. S. Tseng: Electroporation of a foreign gene into black porgy (Acanthopagrus schlegeli) embryos. Fisheries Sci., 60, 787-788 (1994).

9) D. Chourrout and E. Perrot: No transgenic rainbow trout produced with sperm incubated with linear DNA. Mol. Marine Biol. Biotechnol., 1, 282-285 (1992).

10) H. W. Khoo, L. H. Ang, H. B. Lim, and K. Y. Wong: Sperm cells as vectors for introducing foreign DNA into zebrafish. Aquaculture, 107, 1-19 (1992).

11) E. Muller, Z. Ivics, F. Erdelyi, T. Papp, L. Varadi, L. Horvath, N. Maclean, and L. Orban: Introducing foreign genes into fish eggs with electroporated sperm as a carrier. Mol. Marine Biol. Biotechnol., 1, 276-281 (1992).

12) J. E. Symonds, S. P. Walker, and F. Y. T. Sin: Electroporation of salmon sperm with plasmid DNA: evidence of enhanced sperm/ DNA association. Aquaculture, 119, 313-327 (1994).

13) J. E. Symonds, S. P. Walker, F. Y. T. Sin, and I. Sin: Development of a mass gene transfer method in chinook salmon: optimization of gene transfer by electroporated sperm. Mol. Marine Biol. Biotechnol., 3, 104-111 (1994).

14) H. J. Tsai, F. S. Tseng, and I. C. Liao: Electroporation of sperm to introduce foreign DNA into the genome of loach (Misgurnus anguillicaudatus). Can. J. Fish. Aquat. Sci., 52, 776-787 (1995).

15) J. G. Patil and H. W. Khoo: Nuclear internalization of foreign DNA by zebrafish spermatozoa and its enhancement by electroporation. J. Exp. Zool. 274, 121-129 (1996).

16) C. Yanisch-Perron, J. Vieira, and J. Messing: Improved M13 phage cloning vectors and host strains: nucleotide sequences of the M13mp18 and pUC19 vector. Gene, 33, 103-119 (1985).

17) Z. Gong, C. L. Hew, and J. R. Vielkind: Functional analysis and temporal expression of promoter regions from fish antifreeze protein genes in transgenic Japanese medaka embryos. Mol. Marine 
Biol. Biotechnol, 1, 64-72 (1991).

18) T. Maniatis, E. F. Fritsch, and J. Sambrook: Molecular Cloning: A Laboratory Manual. Cold Spring Harbor Laboratory Press, New York, 1982, p. 86-93.

19) A. P. Feinberg and B. Volgestein: A technique for radiolabeling DNA restriction endonuclease fragments to high specific activity. Anal. Biochem., 132, 6-10 (1983).

20) S. J. Du, Z. Gong, G. L. Fletcher, M. A. Shears, M. J. King, D. R. Idler, and C. L. Hew: Growth enhancement in transgenic Atlantic salmon by the use of an "all fish" chimeric growth hormone gene construct. Bio/Technology, 10, 176-181 (1992).
21) T. D. Xie and T. Y. Tsong: Study of the mechanisms of electric field-induced DNA transfection. III. Electric parameters and other conditions for effective transfection. Biophy. J., 63, 28-34 (1992)

22) D. J. Winterbourne, S. Thomas, J. Hermon-Taylor, 1. Hussain, and A. P. Johnstone: Electric shock-mediated transfection of cells: characterization and optimization of electrical parameters. Biochem. J., 251, 427-434 (1988).

23) H. Wolf, M. P. Rols, E. Boldt, E. Neumann, and J. Teissie: Control by pulse parameters of electric field-mediated gene transfer in mammalian cells. Biophy. J., 66, 524-531 (1994). 